\title{
Sustainable Wall Solutions Using Foam Concrete and Hemp Composites
}

\author{
Genadijs SAHMENKO ${ }^{1}$, Maris SINKA ${ }^{2}$, Eva NAMSONE$^{3}$, Aleksandrs KORJAKINS ${ }^{4}$, \\ Diana BAJARE 5 \\ ${ }^{1-5}$ Institute of Materials and Structures, Riga Technical University, Kalku iela 1, Riga, Latvia
}

\begin{abstract}
This work is devoted to developing an energy-efficient solution for the external wall and evaluating its environmental impact. Several types of innovative single-layer and sandwich-type wall solutions were analysed and compared. Different constructive and thermal insulation materials were used, including traditional wall materials such as AAC (autoclaved aerated concrete) and normal concrete. Advanced materials, such as highperformance foamed concrete (HPFC) and natural biofibre composites, have been evaluated as an alternative solution. Ultra-light foam concrete was applied as an alternative for polymer-based insulation. The next development was sandwich three-layer wall constructions consisting of foam concrete and natural biofibre composites. A prototype of a wall panel was elaborated with outer layers of high-density bio-composite and a middle layer of high porosity hemp composite. Basic properties of sandwich blocks, such as density and thermal conductivity, were evaluated and compared. The environmental impact of the studied wall systems was analysed using a life-cycle assessment (LCA) to assess carbon dioxide emissions during the production phase of the material. The results show that replacing traditional insulation with bio-based materials has greatly reduced the negative environmental impact of the wall elements. A combination of natural fibre bio-composite and mineral insulating foam makes it possible to obtain an eco-friendly and sustainable sandwich-type wall system.
\end{abstract}

Keywords - Environmental impact; global warming potential; hemp concrete; foam concrete; magnesium cement; natural bio-composite; sustainability

\begin{tabular}{|ll}
\hline Nomenclature & \\
AAC & Autoclaved aerated concrete \\
HPFC & High-performance foamed concrete \\
LCA & Life-cycle assessment \\
LWAC & Lightweight aggregate concrete \\
GWP & Global warming potential \\
NC & Normal concrete \\
MOC & Magnesium oxychloride cement
\end{tabular}

\section{INTRODUCTION}

The global community and the EU have made a great effort in the last ten years to reduce greenhouse gas emissions, such as $\mathrm{CO}_{2}$. Energy efficiency is one of the ways how to reduce

\footnotetext{
${ }^{*}$ Corresponding author.

E-mail address: genadijs.sahmenko@rtu.lv

C2021 Genadijs Sahmenko, Maris Sinka, Eva Namsone, Aleksandrs Korjakins, Diana Bajare.

This is an open access article licensed under the Creative Commons Attribution License (http://creativecommons.org/ licenses/by/4.0).
} 
emissions in a cost effective way [1]. For instance, the 2030 climate and energy framework [2] focuses on improving energy efficiency by $32 \%$ and reducing $\mathrm{CO}_{2}$ emissions by $40 \%$ by the year 2030. According to the World Green Building Council report [3], the operation of buildings and building construction processes are responsible for $39 \%$ of all carbon emissions in the world, and single family houses have the highest negative impact per person per $\mathrm{m}^{2}[4]$.

A significant part of $\mathrm{CO}_{2}$ emissions is created by the production of construction materials and depends on the energy efficiency of buildings during their exploitation period. Building walls are responsible for up to $35 \%$ of lost heating energy [5]. Therefore, wall systems should be designed by considering necessary thermal insulation, comfortable indoor conditions, and environmental impact (carbon dioxide emissions during the life cycle). The task of the building envelope is to protect against external climatic factors and create favourable microclimate conditions inside the building. An important property of external walls is their bearing capacity, which depends on the mechanical strength of the materials used and design solutions. For centuries, people have used traditional wall materials such as clay bricks, stone, and wood. These materials are both structural and heat-insulating; they combine the basic properties of building envelopes. It must be noted that the requirements for the energy efficiency of external walls are increasing every year. For example, in Latvia, in accordance with today's building regulations, the thermal conductivity ( $U$-value) of the external wall should be no more than $0.2 \mathrm{~W} / \mathrm{mK}$. In using monolithic material, which combines bearing and thermal insulation functions, the necessary calculated thickness of the wall should be at least 400-600 mm [6]. For this reason, sandwich-type (layered) wall construction is considered a more efficient solution because it combines effective load-bearing and thermal insulation properties [7].

Small-size wall blocks are a popular wall solution thanks to fast assembly, precision, and low labour intensity. These may be used for filling concrete framework buildings and as a constructive material for one- or two-story buildings. Different kinds of lightweight concrete (LWC) are usually used as blocks for walls. Lightweight aggregate concrete (LWAC) blocks are produced from lightweight aggregate (such as grains of expanded clay or foamed glass) and cement binder.

Cellular concrete is the most commonly used material. The most popular small-size wall blocks made of autoclaved aerated concrete (AAC). AAC technology implies chemical aeration of a lime-silicate mix and further thermal treatment in a special steam pressure chamber. Foam concrete (FC) blocks are cast from mechanically aerated cement mortar and do not require special thermal treatment. FC may be produced using pre-foaming and mixed-foaming methods. Each type of concrete has its positive and negative sides. AAC blocks are brittle, sensitive to external moisture, and could meet durability problems, whereas FC could be more durable and water-resistant [8]. Usually, FC has lower strength at the same density compared to AAC. However, the studies carried out by article authors indicate that the advanced technology of foam concrete makes it possible to obtain materials superior in their properties to the AAC. A wide density range $\left(300-1600 \mathrm{~kg} / \mathrm{m}^{3}\right)$, thermal conductivity $(0.10-0.66 \mathrm{~W} / \mathrm{mK})$, and compressive strength up to $60 \mathrm{MPa}$ could be obtained [9]. The highly porous structure of cellular concrete determines a low self-weight and has economic benefits because cells occupy up to $85 \%$ of the total volume [10]. This material can be applied both for prefabricated and monolithic elements.

It must be mentioned that traditionally used wall blocks have a significant environmental impact [11], mostly due to using cement as a binder [12]. The use of fibrous bio-composite material is one way to reduce the environmental impact of wall blocks [13]. This insulation material consists of bio-based fibrous aggregate - wood products or agricultural by-products 
and mineral binder [14]. The most studied material in this field is hemp concrete, a composite consisting of hemp shives and hydraulic binders. Traditional hemp concrete is used as in-situ material with a load-bearing wooden frame [15]. In this study, a new type of binder is used for hemp bio-composite - magnesium oxychloride cement. This binder allows for achieving a higher mechanical strength than hemp biofibre composite and is used together with foam concrete to produce eco-friendly wall blocks.

The use of full-size wall panels may be regarded as an effective solution for modern building construction. A high degree of factory readiness allows for constructing both single-story and multi-story buildings throughout the year. Moreover, it makes it possible to increase labour productivity significantly and reduce the cost of construction.

Traditionally, large wall panels are made using concrete as the main material for the bearing layer. The use of dense concrete determines not only the high load-bearing capacity of building elements but also the high dead weight. Modern construction trends provide for the increasingly widespread use of wall panels based on lightweight and natural materials, such as wood and composites made of natural fibres and agricultural by-products [16], [17].

The use of natural building materials has a positive impact on protecting the environment. Life cycle assessment (LCA) is used in this research for analysing the environmental impact of the various building materials, both traditional and alternative. This includes all processes and emissions associated with the production of the material. Although there are many different impact categories, global warming potential (GWP) - measured in $\mathrm{CO}_{2}$ equivalents $\left(\mathrm{CO}_{2}\right.$-eq. $)$ - is used in this research. It has the most topical environmental impact, and the construction industry contributes a significant amount of global $\mathrm{CO}_{2}$ emissions [18].

The aim of this work is to regard new energy-efficient solutions for the structure of external walls as an alternative to the existing traditional wall, such as insulated reinforced concrete panels and autoclaved aerated concrete. The authors propose to use high-performance foam concrete and natural composites based on hemp fibres and magnesium binder.

In this study, wall systems with similar thermal transmittance were selected. When analyzing wall systems, the main criterion was their environmental impact, based on evaluation of LCA and comparison of global warming potential.

\section{MATERials AND MethodS}

Several types of wall structures have been reviewed and compared in this research. Analysed monolithic and sandwich wall systems were selected to provide a $U$-value close to $0.17-0.20 \mathrm{~W} / \mathrm{m}^{2} \mathrm{~K}$. It corresponds to standard requirements for wall constructions in the climatic conditions of Northern Europe. Total wall thickness was limited to $600 \mathrm{~mm}$. Nine types of wall systems are presented. The first four types are walls made of monolithic material, which combines thermal insulation and load-bearing properties. The next five solutions present sandwich systems. Initially, the materials used for wall elements are described. After that, the characteristics of the wall elements used for the environmental impact assessment are given.

\subsection{Materials}

Table 1 summarizes the materials used for wall elements and corresponding general properties, such as compressive strength, dry density, and coefficient of thermal conductivity. It should be noted, that the wall materials used in the study, such as foam concrete and hemp composite, were developed and tested in the laboratory by the authors of the article. In addition, commercially used materials, such as autoclaved concrete, normal concrete, 
mineral wool, and expanded polystyrene, were used for comparison. The properties of these materials were taken from the manufacturer's data. To analyse the environmental impact, it is necessary to know the composition of the material. For this purpose, the table shows the proportions of components per cubic meter of materials (mix compositions are shown in parentheses).

The first three types of materials represent the group of lightweight cellular concrete. These materials are attractive both from the ecological and economic point of view since the main filler is air, which occupies a large part of the volume. Nowadays, it is technologically possible to produce aerated concrete of various densities ranging from $200-1800 \mathrm{~kg} / \mathrm{m}^{3}$. Only concretes with a density not higher than $500 \mathrm{~kg} / \mathrm{m}^{3}$ are acceptable to ensure thermal insulation properties. The lower limit of the bearing capacity of wall elements is the compressive strength of 1-3 MPa. This can be achieved at a density of not less than $300 \mathrm{~kg} / \mathrm{m}^{3}$ [19]. Thus, the compromise between strength and thermal conductivity is in a very narrow density range.

Autoclaved Aerated Concrete (AAC) is a popular and cost-effective wall material in Baltic countries. Local and available raw materials of lime and quartz sand are used for its production. From an environmental point of view, the most vulnerable technological stage is the autoclaving treatment, which requires considerable energy consumption due to the high pressure and elevated temperature used in the technological process.

Foam concrete, unlike aerated concrete, does not require heat treatment during production. Moreover, foam concrete technology makes it possible to produce it both in monolithic and prefabricated versions [20] in a wide range of densities. Cement is the most environmentally influential component of foam concrete.

High-performance foam concrete (HPFC) is elaborated on to improve its mechanical properties and durability. HPFC is produced by cavitation mixed-foaming technology and is characterized by its mechanical strength, durability, and ductility, comparable to AAC. Previous studies [21] proved the benefits of highly intensive mixing technology that provides mix homogeneity and promotes accelerated hydration and the effective use of cement. Lowdensity HPFC $\left(<450 \mathrm{~kg} / \mathrm{m}^{3}\right)$ may be used as a monolith insulation material [8]. Simultaneous use of light foam glass aggregates and cavitation technology makes it possible for the mechanical properties of this material to approach the properties of autoclaved aerated concrete (close to $1.5 \mathrm{MPa}$, providing a density of $350 \mathrm{~kg} / \mathrm{m}^{3}$ ). In this case, foam glass granules with a bulk density of $120-150 \mathrm{~kg} / \mathrm{m}^{3}$ were used as a filling material (Table 1).

High-density foam concrete $\left(800-1000 \mathrm{~kg} / \mathrm{m}^{3}\right)$ is used as a load-bearing material in the composition of industrially produced sandwich blocks (Warmhouse ${ }^{\odot}$ Ltd.). Expanded polystyrene (EPS) was used as a thermal insulating layer in the composite block. Despite the polymer origin, at present, EPS is one of the most economical and effective insulating materials. At the same time, there is conflicting information about its environmental safety over a long period of operation [22], [23]. Therefore, within the framework of ecological construction, it would be wise to replace this material with natural biofibre insulating materials.

A concrete wall structure with additional mineral wool insulation was used as reference material. Normal concrete (NC) today is the main structural material for mass construction. The traditional solution is a reinforced concrete wall insulated outside with mineral wool or expanded polystyrene. Compared with other light materials considered in this work, NC has the highest structural packing density and the lowest porosity. Thus, concrete has low vapour permeability and moisture buffering capacity; therefore, it cannot naturally regulate the indoor climate. 
TABLE 1. MATERIALS APPLIED IN REVIEWED WALl StRUCTURES

\begin{tabular}{|c|c|c|c|c|}
\hline Material & General components, $\mathrm{kg} / \mathrm{m}^{3}$ & $R_{\mathrm{c}}, \mathrm{MPa}$ & $\rho_{0}, \mathbf{k g} / \mathbf{m}^{3}$ & $\lambda, \mathbf{W} / \mathbf{m K}$ \\
\hline $\begin{array}{l}\text { Autoclaved Aerated } \\
\text { Concrete }\end{array}$ & $\begin{array}{l}\text { Lime, ground quartz sand, admixtures } \\
\text { (industrially produced), water }\end{array}$ & 1.5 & 350 & 0.085 \\
\hline $\begin{array}{l}\text { High Performance } \\
\text { Foam Concrete }\end{array}$ & Cement (200), Sand (150), admixtures, water & 1.5 & 450 & 0.11 \\
\hline $\begin{array}{l}\text { High Performance } \\
\text { Foam Concrete } \\
\text { with foam glass } \\
\text { grains }\end{array}$ & $\begin{array}{l}\text { Cement (140), Sand (100), Foam glass grains } \\
(50) \text {, foaming agent, water }\end{array}$ & 1.5 & 350 & 0.085 \\
\hline Normal concrete & $\begin{array}{l}\text { Cement (330), Sand (750), crushed aggregate } \\
(1000)\end{array}$ & 35 & 2400 & 1.3 \\
\hline Mineral wool & Basalt fibres, binding resin binder & - & 100 & 0.037 \\
\hline Foam concrete & Cement (450), Sand (300), admixtures, water & 8.0 & 1000 & 0.23 \\
\hline $\begin{array}{l}\text { Expanded } \\
\text { polystyrene EPS }\end{array}$ & & & 20 & 0.033 \\
\hline $\begin{array}{l}\text { Lime based hemp } \\
\text { comp. Lightweight }\end{array}$ & $\begin{array}{l}\text { Hemp shive/lime/pozzolanic admixture/water } \\
(100 / 60 / 40 / 175)\end{array}$ & 0.07 & 265 & 0.064 \\
\hline Dense & $(100 / 120 / / 80 / 225)$ & 0.15 & 368 & 0.082 \\
\hline $\begin{array}{l}\text { MOC hemp } \\
\text { composite dense }\end{array}$ & $\begin{array}{l}\text { Hemp shive (100), } \mathrm{MgO}(200), \mathrm{MgCl}_{2} \text { solution } \\
\text { (125), water (150) }\end{array}$ & 2.00 & 450 & 0.13 \\
\hline $\begin{array}{l}\text { MOC hemp } \\
\text { composite }\end{array}$ & $\begin{array}{l}\text { Hemp shive (100), } \mathrm{MgO}(90), \mathrm{MgCl}_{2} \text { solution } \\
\text { (55), water (150) }\end{array}$ & 0.50 & 265 & 0.064 \\
\hline
\end{tabular}

Designations: $R_{\mathrm{c}}$ - compressive strength, $\rho_{\mathrm{o}}$ - material dry density, $\lambda$ - coefficient of thermal conductivity

At present, using natural fibrous materials as a building insulation material is being revived more and more in the world. Hemp concrete is the most famous and popular material in the creation of environmentally friendly envelope systems. Moreover, bio-composite materials are characterized by excellent hygrothermal properties that provide favourable temperatures and humidity indoors [24], [25]. Hardening of lime binders takes place with the carbonization process sequestering some of the $\mathrm{CO}_{2}$ released in the production process [15]. Low strength and slow hardening are the main disadvantages of lime-based composites. The use of various additives provides an opportunity to improve the mechanical properties of lime binders [14], [26].

Improved hemp-based composites have been developed and tested using magnesium oxychloride cement (MOC) binder to enhance the performance of biofibre composites. MOC is high early strength air-hardening cementitious material developed at the end of the $19^{\text {th }}$ century, and it is also known as Sorel cement [27]. The main advantage of this material is the excellent adhesion of the magnesia binder to the cellulosic aggregate. This makes it possible to obtain lighter materials at the same strength [6]. Within the framework of the study, MOC hemp bio-composite materials were developed with a density of 265 and $450 \mathrm{~kg} / \mathrm{m}^{3}$.

In the laboratory, a significant number of experiments were carried out to determine the thermal conductivity of various formulations of hemp biofibre compositions. It should be noted that the determining factor affecting thermal conductivity is the density of the material, regardless of what type of binder was used. The relationship between the density and the 
thermal conductivity of hemp bio-composite materials is presented in Fig. 1. Formulations on magnesia binders are marked in red, but lime-based compositions are marked in green. The trendline is in line with other author findings [28].

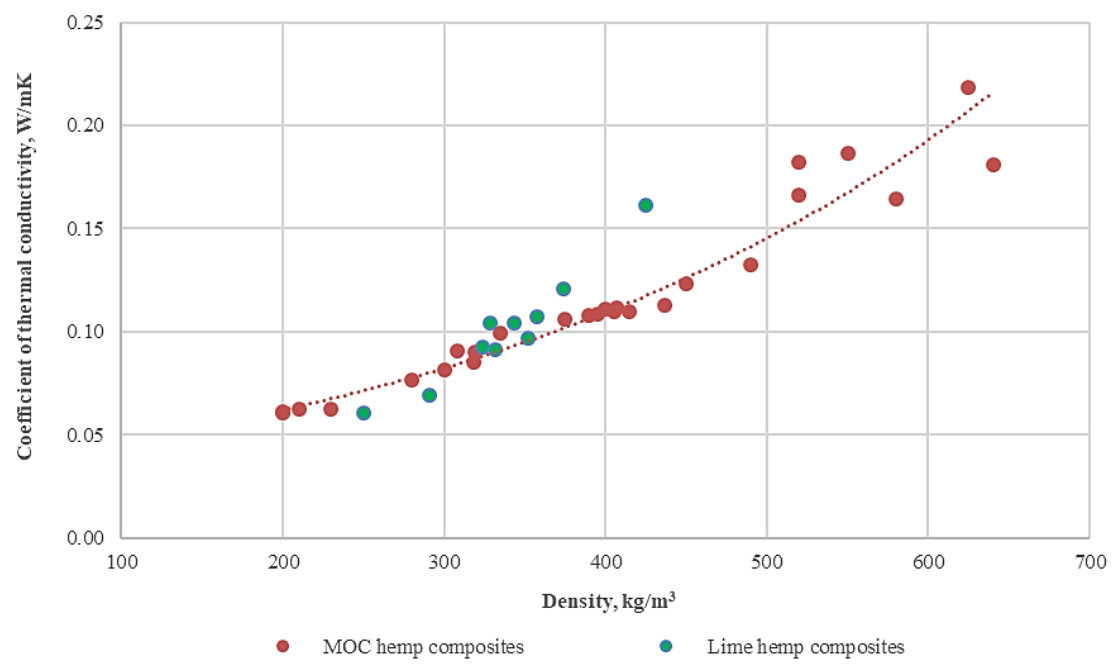

Fig. 1. Relation Dry density - coefficient of thermal conductivity.

\subsection{Methodology}

The basic physical and mechanical properties of used materials were tested experimentally in the laboratory. Compressive strength $\left(R_{\mathrm{c}}\right)$ was determined in accordance EN 772-1. Methods of test for masonry units - Part 1: Determination of compressive strength. The coefficient of thermal conductivity $\lambda$ was tested by using Laser Comp heat flow measurement device FOX 600 in accordance to EN 12667.

$U$-value (thermal transmittance, $\mathrm{W} / \mathrm{m}^{2} \mathrm{~K}$ ) is the rate of transfer of heat through a wall structure. $U$-value of individual separate layer is calculated as a relation of coefficient of thermal conductivity of material $(\lambda, \mathrm{W} / \mathrm{mK})$ and layer thickness $(T, \mathrm{~mm})$.

In the scope of this research, LCA was carried out according to ISO 14040/44 guidelines. The goal of the LCA is to assess the global warming potential (GWP) of different wall construction types, mainly focusing on mineral foam and biofibre composite materials and comparing them to the traditionally used wall constructions. Cradle-to-gate system boundaries were used.

The LCA calculation software SimaPro 8 were used, and the calculations were performed according to the GWP 100a method. The functional unit was defined as a $1 \mathrm{~m}^{2}$ of wall with a similar U-value; this allows to compare the different construction types with each other. The $U$-value was set in range between $0.17-0.20 \mathrm{~W} / \mathrm{m}^{2} \mathrm{~K}$. The Ecoinvent database was used for most of the processes along with additional data from research about the LCA of hempcrete [6], hemp-magnesium panels [7], and foam concrete [6], [10]. 


\section{RESUlts AND DiscusSiONS}

\subsection{Wall System Samples Used for Life-Cycle Assessment}

Wall system samples used for LCA are summarized in Table 2. Sample numbers 1, 2, and 3 are monolithic wall blocks.

- Sample 1 is commercially used autoclaved aerated concrete (AAC) blocks having a width of $500 \mathrm{~mm}$ and a $U$-value of $0.17 \mathrm{~W} / \mathrm{m}^{2} \mathrm{~K}$;

- Sample 2 is monolithic high-performance foam concrete (HPFC) blocks with a width of $600 \mathrm{~mm}$ and a density of $450 \mathrm{~kg} / \mathrm{m}^{3}$. Increased width is needed to provide a $U$-value of $0.18 \mathrm{~W} / \mathrm{m}^{2} \mathrm{~K}$. Compressive strength is close to $1.5 \mathrm{MPa}$. This foam concrete has been prepared using an industrial turbulence mixer with the effect of cavitation;

- Sample 3 is HPFC improved by adding foam glass aggregate (Fig. 2). It was proved [29] that the use of intensive mixing technologies combined with lightweight fillers is a way to achieve the lowest water absorption values and drying shrinkage, among other types of cellular concretes. Furthermore, this composition is characterized by thermal transmittance of $0.18 \mathrm{~W} / \mathrm{m}^{2} \mathrm{~K}$. It is comparable to the AAC block;

- Sample 4 (Fig. 6) is an example of a traditional hemp concrete wall produced with hydrated lime. In practice, the following technology for erecting a monolithic wall from hemp concrete schemes is used. Initially, a wooden wall frame is installed. Then, using sliding formwork, the volume of the wall is filled with a lime-hemp mixture. Finally, the wall surface is covered with a layer of lime plaster to protect against climatic influences and increase fire resistance. The load-bearing wooden frame was considered in the GWP calculations. A mixture of hemp and binder was taken from previous studies [6] with a density of $368 \mathrm{~kg} / \mathrm{m}^{3}$ and compressive strength of $0.15 \mathrm{MPa}-\mathrm{a}$ minimum for monolithic hempcrete structures.

- Sample 5 is a commercially used $120-\mathrm{mm}$ load-bearing concrete wall with $200 \mathrm{~mm}$ of rock wool insulation and a total thermal transmittance value of $U=0.18 \mathrm{~W} / \mathrm{m}^{2} \mathrm{~K}$. This construction and AAC (Sample 1) can be regarded as a reference to traditional wall systems for comparison with proposed wall solutions.

- Sample 6 is an industrially produced sandwich foam concrete block (Fig. 3 and Fig. 4) with EPS thermal insulation. Sandwich foam concrete block consists of an outer and inner layer of 60 and $100 \mathrm{~mm}$ thick $1000 \mathrm{~kg} / \mathrm{m}^{3}$ dense foam concrete with a middle EPS layer of $140-\mathrm{mm}$ thickness, providing a total $U$-value of $0.20 \mathrm{~W} / \mathrm{m}^{2} \mathrm{~K}$.

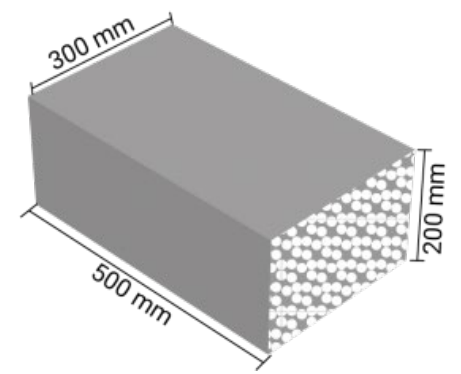

Fig. 2. High-Performance Foam concrete block with foam glass aggregate (Sample 3). 


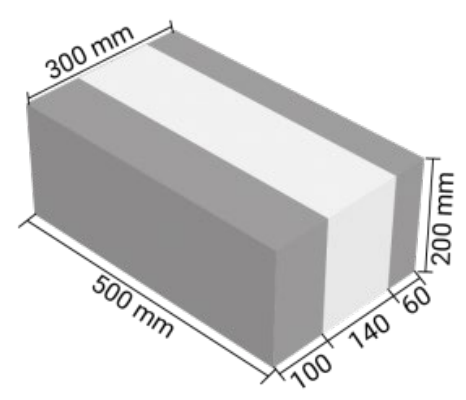

Fig. 3. Industrially produced sandwich foam concrete block with EPS thermal insulation (Sample 6).

- Sample 7 (Fig. 4) is an experimental sandwich hemp-foam block consisting of an outer and inner layer of $100-\mathrm{mm}$ thick medium-density MOC hemp concrete and lightweight $\left(350 \mathrm{~kg} / \mathrm{m}^{3}\right)$ foam concrete of $200-\mathrm{mm}$ thickness, providing a total $U$-value of $0.20 \mathrm{~W} / \mathrm{m}^{2} \mathrm{~K}$. This approach could considerably improve fire resistance and exploitation safety of the wall elements.

- Sample 8 (Fig. 5) is a prototype of a previously elaborated and patented [7] hempmagnesium sandwich panel with various density hemp concrete and a load-bearing wooden frame, $370-\mathrm{mm}$ total thickness, $U=0.18 \mathrm{~W} / \mathrm{m}^{2} \mathrm{~K}$.

- Sample 9 (Fig. 7) is a prototype of a newly developed panel for a prefabricated building. Panel construction is similar to sample number 8 , but a lightweight limebased biofibre composite replaces the inner layer. This system can find a wider practical application in construction since lime composite is more accessible, cheaper, and has a large vapour-buffering capacity.

It must be noted that the last two construction types (Samples 8 and 9), as well as a traditional hemp concrete wall (Sample 4) require an additional load-bearing wooden frame that was considered when conducting LCA.

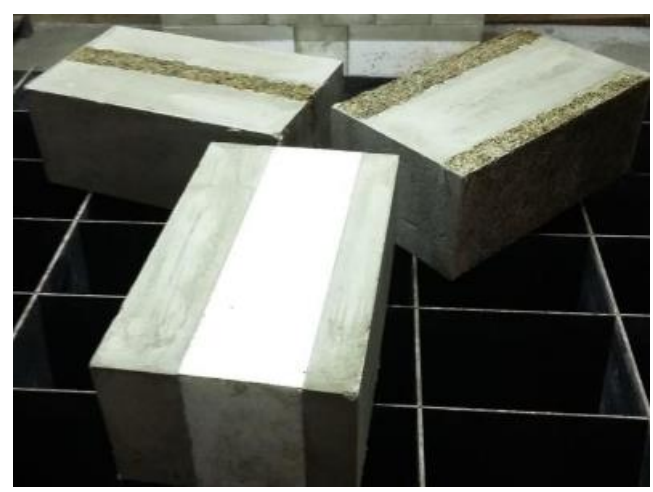

Fig. 4. Experimental foam blocks (industrially produced): sample 6 (at the front), sample 7 hemp-foam concrete-hemp (Sample 7, on the right). 


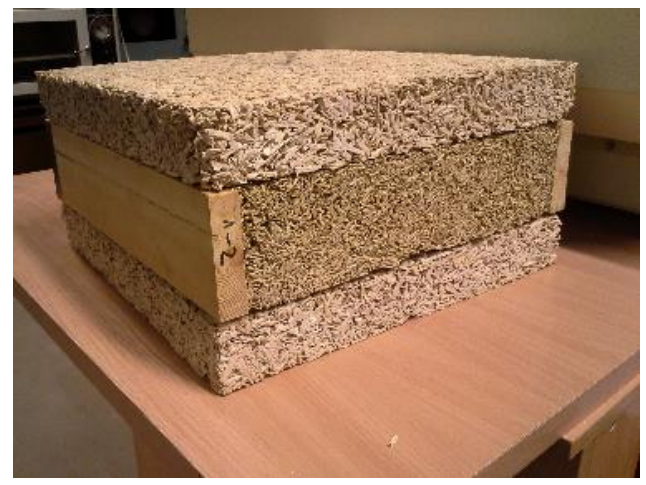

Fig. 5. Experimental sandwich hemp-magnesium sandwich panel (sample with various density hemp concrete).

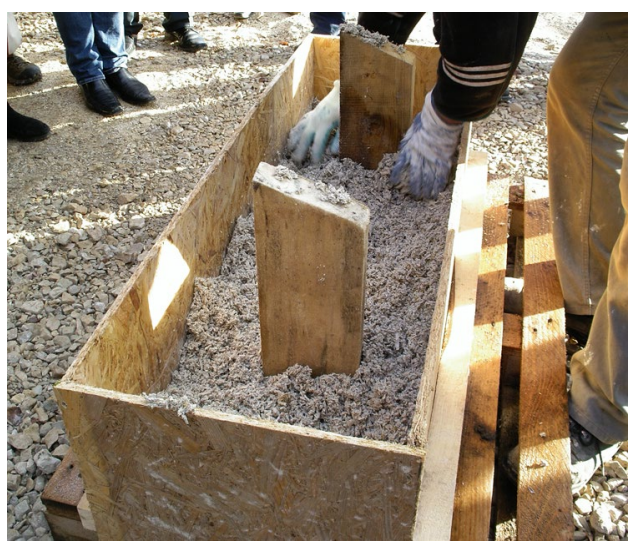

Fig. 6. Lime based hemp biofibre composite monolithic wall (Sample 4): lime-hemp mixture filling in sliding formwork. Hemp Eco Systems Latvia Ltd. Workshop.

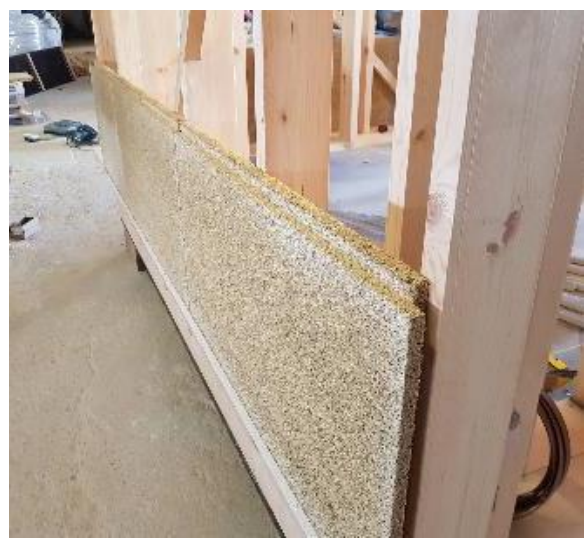

Fig. 7. Sandwich hemp concrete wall full-sized panel: dense MOC-hemp composite slabs on the outer sides; light-weight lime-hemp composite to be filled in internal layer. 


\subsection{Results of the Evaluation of Physical Properties and Life-Cycle Assessment}

The results of the evaluation of the physical properties (including thermal resistance, thermal conductivity, and self-weight) and $\mathrm{CO}_{2}$ emission calculation results for different external wall systems are summarized in Table 2 and Fig. 8.

It may be noted when comparing different wall systems that monolithic blocks require more wall thickness to provide necessary thermal conductivity: $500 \mathrm{~mm}$ is required for AAC concrete blocks and foam concrete with foam glass grains. An increased wall thickness of $600 \mathrm{~mm}$ is required for foam concrete without foam glass granules. This is due to the impossibility of simultaneously providing low density, low coefficient of thermal transmission and sufficient load-bearing capacity.

Sandwich systems with traditional thermal insulation have the least thickness of around $300 \mathrm{~mm}$ for a concrete wall insulated with rock wool (sample 5) and a foam concrete block with incorporated EPS insulation (sample 6). At the same time, an insulated concrete wall has the highest self-weight $\left(326 \mathrm{~kg} / \mathrm{m}^{2}\right)$, but the monolithic high-performance foam concrete wall has the second-highest self-weight $\left(270 \mathrm{~kg} / \mathrm{m}^{2}\right)$.

The sandwich MOC biofibre hemp system (sample 8) has 7.5 lower $\mathrm{CO}_{2}$ emissions, comparing to Sample 5 insulated normal concrete wall $\left(12.7 \mathrm{vs} 95.5 \mathrm{~kg} / \mathrm{m}^{2}\right)$. Low GWP can be explained by the origin of hemp shives as a by-product of hemp fibre production. During the growth of hemp plants, $\mathrm{CO}_{2}$ has been sequestered in the hemp plants and, subsequentially, in the hemp shives. It must be noted that the MOC hemp composite sandwich system (sample 8) has the lowest self-weight $\left(91 \mathrm{~kg} / \mathrm{m}^{2}\right), 3.6$ times lower than insulated concrete wall.

Composite block (sample 7) is a compromise solution that includes foam concrete and biofibre composite material. It has about three times less $\mathrm{CO}_{2}$ emissions than pure cellular concrete blocks but 2.5 times higher than Sample 8 .

It is important to note that despite excellent physical and mechanical properties, HPFC blocks with foam glass grains (sample 3 ) have the highest GWP value $\left(117 \mathrm{~kg} / \mathrm{m}^{2}\right)$. At the same time, this material has performed the highest exploitation safety because it does not contain decomposing organic components. In this case, the phenomenon of a high GWP value is explained by the high environmental impact of foamed glass grains, the main component of improved foam concrete. These also require a significant amount of energy in the production process, and a large amount of cement is required. If alternative types of cement with a lower environmental impact or foam glass from recycled glass were used, it is possible to lower the environmental impact of this block by up to $30 \%$ [12]. Samples 1, 2, 5, and 6 have a similar GWP (82-96 kg CO $\left.2-\mathrm{eq} / \mathrm{m}^{2}\right)$ due to a large amount of cement consumption.

It should be noted that the best solution in the light of environmental protection is a wall structure from traditional hemp concrete (sample 4). This wall has a negative balance of carbon dioxide $\left(-30.91 \mathrm{CO}_{2}-\mathrm{eq} / \mathrm{m}^{2}\right)$. This can be explained by the fact that hemp absorbs carbon dioxide during the growth process, and the absorption of carbon dioxide continues during the hardening of the lime binder [18]. The disadvantage of this construction is a large amount of manual work, which determines the relatively high final cost.

The last developed solution for external walls (sample 9) may be regarded as a compromise between sustainability and the possibility for industrialization of construction work. This wall system has a negative balance of carbon dioxide emissions $\left(-9.5 \mathrm{~kg} \mathrm{CO}\right.$-eq/ $\left./ \mathrm{m}^{2}\right)$. In this case, the negative balance of carbon dioxide is provided by the lime biofibre composite, but the magnesium component has a slightly positive GWP potential. 
TABle 2. EVAluation OF PHYSICAL PROPERTIES AND $\mathrm{CO}_{2}$ EMISSION FOR DifFERENT EXTERNAL WALL SYSTEMS

\begin{tabular}{|c|c|c|c|c|c|c|c|}
\hline Type & Material & $\begin{array}{l}\rho_{0}, \\
\mathrm{~kg} / \mathrm{m}^{3}\end{array}$ & $\begin{array}{l}\lambda, \\
\mathbf{W} / \mathbf{m K}\end{array}$ & $T, \mathbf{m}$ & $\begin{array}{l}\boldsymbol{U}, \\
\mathbf{W} / \mathbf{m}^{2} \mathbf{K}\end{array}$ & $G, \mathrm{~kg} / \mathrm{m}^{2}$ & $\begin{array}{l}\text { GWP, } \mathbf{k g} \\
\mathrm{CO}_{2}-\mathrm{eq} / \mathbf{m}^{2}\end{array}$ \\
\hline $\begin{array}{l}\text { 1. Monolytic } \\
\text { block AAC }\end{array}$ & $\begin{array}{l}\text { Autoclaved Aerates } \\
\text { Concrete (AAC) }\end{array}$ & 350 & 0.085 & 0.50 & 0.17 & 175 & 82.8 \\
\hline $\begin{array}{l}\text { 2. Monolytic } \\
\text { block FC }\end{array}$ & $\begin{array}{l}\text { High Performance Foam } \\
\text { Concrete }\end{array}$ & 450 & 0.11 & 0.60 & 0.18 & 270 & 91.5 \\
\hline \multirow[t]{3}{*}{$\begin{array}{l}\text { 3. Monolytic } \\
\text { block FCG }\end{array}$} & $\begin{array}{l}\text { High Performance Foam } \\
\text { Concrete with foam glass } \\
\text { grains }\end{array}$ & 350 & 0.085 & 0.50 & 0.17 & 175 & 117.0 \\
\hline & $\begin{array}{l}\text { Lime based hemp comp. } \\
\text { Lightweight }\end{array}$ & 368 & 0.082 & 0.453 & 0.18 & 167 & \\
\hline & Total & & & 0.453 & 0.18 & 167 & -30.91 \\
\hline \multirow{4}{*}{$\begin{array}{l}\text { 5. Sandwich } \\
\text { structure } \\
\text { (traditional } \\
\text { concrete } \\
\text { framework) }\end{array}$} & Normal concrete (NC) & 2400 & 1.3 & 0.12 & 10.83 & 288 & \\
\hline & Steel mesh $12 \times 200 \mathrm{~mm}$ & & & & & 18 & \\
\hline & Mineral wool & 100 & 0.037 & 0.20 & 0.19 & 20 & \\
\hline & Total & & & 0.32 & 0.18 & 326 & 95.5 \\
\hline \multirow{4}{*}{$\begin{array}{l}\text { 6. Sandwich } \\
\text { foam concrete } \\
\text { block }\end{array}$} & Foam concrete & 1000 & 0.23 & 0.06 & 3.83 & 60 & \\
\hline & Foamed polystyrene & 20 & 0.033 & 0.14 & 0.24 & 2.8 & \\
\hline & Foam concrete & 1000 & 0.23 & 0.10 & 2.30 & 100 & \\
\hline & Total & & & 0.30 & 0.20 & 163 & 82.4 \\
\hline \multirow{4}{*}{$\begin{array}{l}\text { 7. Sandwich } \\
\text { hemp-foam } \\
\text { block }\end{array}$} & $\begin{array}{l}\text { Medium density MOC hemp } \\
\text { composite }\end{array}$ & 330 & 0.077 & 0.10 & 0.77 & 33 & \\
\hline & Lightweight HPFC & 350 & 0.08 & 0.20 & 0.40 & 70 & \\
\hline & $\begin{array}{l}\text { Medium density MOC hemp } \\
\text { composite }\end{array}$ & 330 & 0.077 & 0.10 & 0.77 & 33 & \\
\hline & Total & & & 0.40 & 0.20 & 136 & 33.4 \\
\hline \multirow{4}{*}{$\begin{array}{l}\text { 8. Sandwich } \\
\text { hemp block }\end{array}$} & $\begin{array}{l}\text { Dense MOC hemp } \\
\text { composite }\end{array}$ & 450 & 0.13 & 0.03 & 4.33 & 13.5 & \\
\hline & $\begin{array}{l}\text { Lightweight MOC hemp } \\
\text { composite }\end{array}$ & 210 & 0.062 & 0.29 & 0.21 & 60.9 & \\
\hline & $\begin{array}{l}\text { Medium density MOC hemp } \\
\text { composite }\end{array}$ & 330 & 0.077 & 0.05 & 1.54 & 16.5 & \\
\hline & Total & & & 0.37 & 0.18 & 91 & 12.7 \\
\hline \multirow{4}{*}{$\begin{array}{l}\text { 9. Lime-MOC } \\
\text { hemp } \\
\text { composite } \\
\text { precast panel }\end{array}$} & $\begin{array}{l}\text { Dense MOC hemp } \\
\text { composite }\end{array}$ & 450 & 0.13 & 0.045 & 2.89 & 20.25 & \\
\hline & $\begin{array}{l}\text { Lime based hemp comp. } \\
\text { Dense }\end{array}$ & 265 & 0.064 & 0.310 & 0.21 & 82.15 & \\
\hline & $\begin{array}{l}\text { Dense MOC hemp } \\
\text { composite }\end{array}$ & 450 & 0.13 & 0.045 & 2.89 & 20.25 & \\
\hline & Total & & & 0.400 & 0.18 & 123 & -9.5 \\
\hline
\end{tabular}

Designations: $\rho_{\mathrm{o}}-$ material dry density, $\lambda$ - coefficient of thermal conductivity, $T$ - thickness, $U$ - thermal transmittance, $G$ - self-weight, GWP - global warming potential. 
Samples with hemp-based fibre composites (samples 4 and 9) have similar self-weight close to $168 \mathrm{~kg} / \mathrm{m}^{2}$. The weight of these structures is half the weight of an insulated reinforced concrete wall.

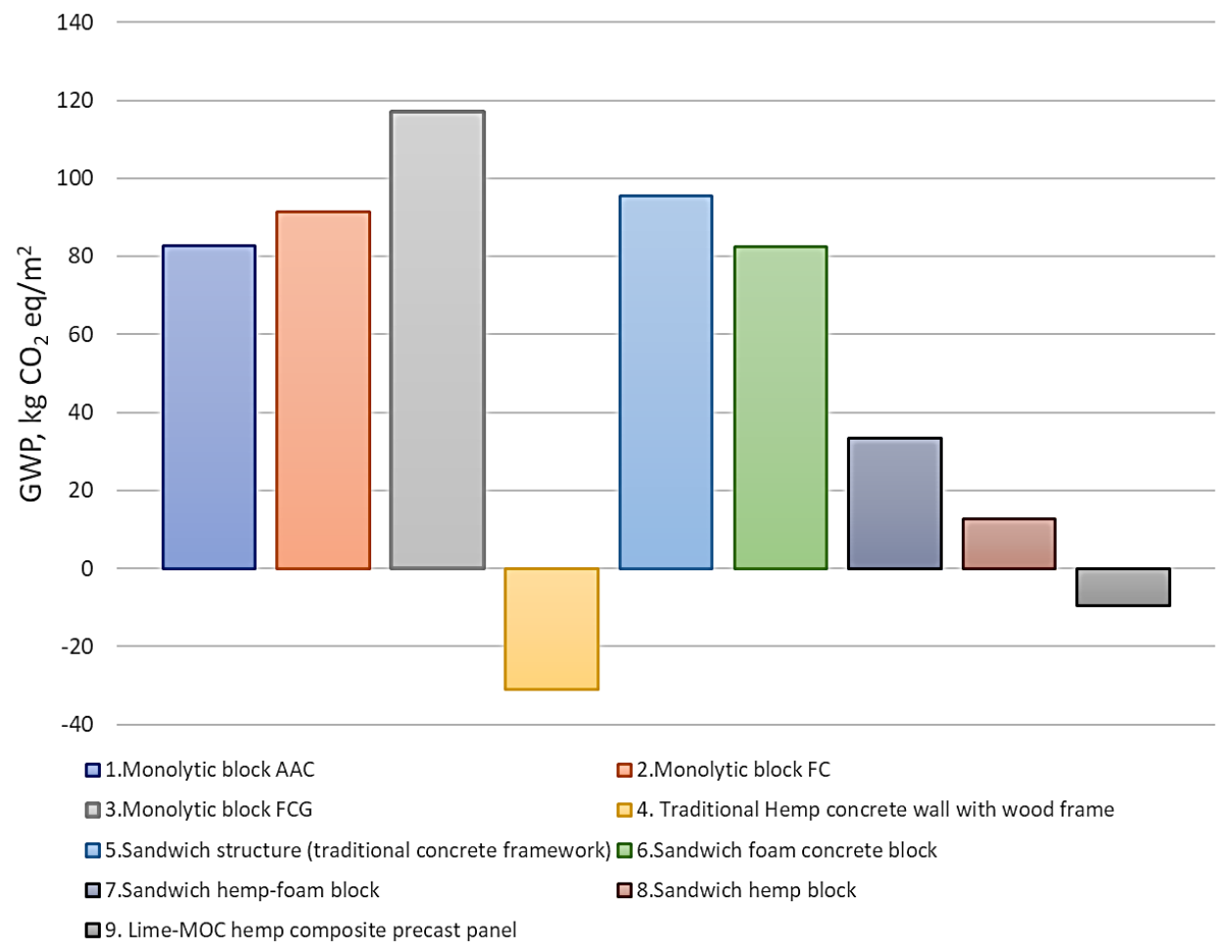

Fig. 8. $\mathrm{CO}_{2}$ emissions for different external wall systems with similar $U$ value.

\section{Conclusions}

The use of the sandwich wall system provides more effective utilization of raw materials: wall thickness may be reduced from 500-600 mm using single-layer AAC and HPFC to up to $300 \mathrm{~mm}$ thick wall using the sandwich block system.

The life-cycle assessment results show that insulated normal concrete wall, AAC, and foam concrete are characterized by high $\mathrm{CO}_{2}$ emission due to the high GWP of Portland cement. The replacement of traditional materials with bio-based materials greatly reduces the environmental impact of the sandwich blocks. A combination of natural fibre bio-composite and mineral insulating foam makes it possible to obtain an eco-friendly and sustainable sandwich-type wall system.

On the other hand, it must be noted that GWP is just one of the environmental impact categories. To completely assess the environmental impact of the studied materials, more comprehensive research is needed. Furthermore, the exploitation safety of the material should be considered along with the indoor microclimate that the wall system can provide as both influence human health and well-being.

The highest negative carbon dioxide balance $\left(-30.91 \mathrm{CO}_{2}\right.$-eq $\left./ \mathrm{m}^{2}\right)$ is provided by a monolithic lime biofibre composite wall. A good alternative solution is to use a magnesium-based (MOC) 
biofibre composite that has better mechanical properties and allows to obtain a lighter material with better thermal insulation properties.

The most promising option for modern construction is the developed three-layer panel, which consists of outer layers of hard MOC biofibre composite and an inner part of lime-based light biofibre composite. This solution may be advisable both from environmental protection and economic points of view and to ensure comfortable indoor conditions.

This study proved the possibility of replacing traditional wall materials with alternative natural materials based on hemp fibre and mineral binder. The developed wall structures are not inferior to traditional wall systems in terms of thermal insulation requirements, but these have a significantly less environmental impact and GWP.

\section{ACKNOWLEDGEMENT}

Project "Manufacturing technology of building products made of ecological high performance fibre composites with encapsulated PCM for the NZEB application" (HEMP4NZEB) is supported by M-EraNet programme and State Education Development Agency Republic of Latvia, Grant Agreement Nr. ESRTD/2020/8.

\section{REFERENCES}

[1] Locmelis K., et al. Industrial Energy Efficiency Towards Green Deal Transition. Case of Latvia. Environmental and Climate Technologies 2021:25:42-57. https://doi.org/10.2478/rtuect-2021-0004

[2] European Union. Energy and Climate framework 2030, European Council 23/24 October 2014 - Conclusions. Brussels: EUCO, 2014:169/14.

[3] World Green Building Council. New report: the building and construction sector can reach net zero carbon emissions by 2050 [Online]. [Accessed 11.03.2021]. Available: https://www.worldgbc.org/news-media/WorldGBC-embodiedcarbon-report-published

[4] Vamza I., et al. Life Cycle Assessment of Reprocessed Cross Laminated Timber in Latvia. Environmental and Climate Technologies 2021:25:58-70. https://doi.org/10.2478/rtuect-2021-0005

[5] Energy efficiency in traditional buildings. Dublin: Government of Ireland, 2010.

[6] Sinka M., et al. Comparative life cycle assessment of magnesium binders as an alternative for hemp concrete. Resources, Conservation and Recycling 2018:133:288-299. https://doi.org/10.1016/j.resconrec.2018.02.024

[7] Sinka M., et al. Bio-based construction panels for low carbon development. Energy Procedia 2018:147:220-226. https://doi.org/10.1016/j.egypro.2018.07.063

[8] Namsone, E., Šahmenko, G. and Korjakins, A. Durability Properties of High Performance Foamed Concrete. Procedia Engineering 2017:172:760-7. https://doi.org/10.1016/j.proeng.2017.02.120

[9] Zahari N. M., et al. Foamed Concrete: Potential Application in Thermal Insulation. Proceedings of MUCEET2009 Malaysian Technical Universities Conference on Engineering and Technology 2009:47-52.

[10] Namsone E., et al. The environmental impacts of foamed concrete production and exploitation. IOP Conference Series: Materials Science and Engineering 2017:251:012029. https://doi.org/10.1088/1757-899X/251/1/012029

[11] Zimele Z., et al. Life cycle assessment for masonry exterior wall assemblies made of traditional building materials. IOP Conference Series: Materials Science and Engineering 2019:660:012042. https://doi.org/10.1088/1757$\underline{899 X / 660 / 1 / 012042}$

[12] Zimele Z., et al. Life Cycle Assessment of Foam Concrete Production in Latvia. Environmental and Climate Technologies 2019:23:70-84. https://doi.org/doi:10.2478/rtuect-2019-0080

[13] Collet F. Hygric and Thermal Properties of Bio-aggregate Based Building Materials. In Amziane S., Collet F. (eds) Bio-Aggregates Based Building Materials. State-of-the-Art Report of the RILEM Technical Committee 236-BBM. Dordrecht: Springer Netherlands, 2017:125-147. https://doi.org/10.1007/978-94-024-1031-0_6

[14] Amziane S., Arnaud L., Challamel N. Bio-aggregate-based Building Materials. John Wiley \& Sons, Inc., 2013. https://doi.org/10.1002/9781118576809

[15] Jami T., Karade S. R., Singh, L. P. A review of the properties of hemp concrete for green building applications. Journal of Cleaner Production 2019:239:17852. https://doi.org/10.1016/j.jclepro.2019.117852

[16] Ahlberg J., Georges E., Norlén M. The potential of hemp buildings in different climates and the hempcrete building system The potential of hemp buildings in different climates. Bs. thesis. Uppsala: Uppsala Universitet, 2014.

[17] Bourdot A., et al. Characterization of a hemp-based agro-material: Influence of starch ratio and hemp shive size on physical, mechanical, and hygrothermal properties. Energy and Buildings 2017:153:501-512. https://doi.org/10.1016/j.enbuild.2017.08.022 
[18] Florentin Y., et al. A life-cycle energy and carbon analysis of hemp-lime bio-composite building materials. Energy and Buildings 2017:156:293-305. https://doi.org/10.1016/j.enbuild.2017.09.097

[19] Namsone E., et al. Thermal conductivity and frost resistance of foamed concrete with porous aggregate. Environment, Technology, Resources. Proceedings of the International Scientific and Practcal Conference 2017:222-228. https://doi.org/10.17770/etr2017vol3.2625

[20] Kavita M., Tarjani C. Comparison on Auto Aerated Concrete to Normal Concrete. Recent Advances in Civil Engineering for Global Sustainability 2016:90-94.

[21] Šahmenko G., Korjakins A., Namsone E. High Performance Foam Concrete Produced in Turbulence Mixers. Proceedings of International Conference Towards a Sustainable Built Environment: SBE16 Malta 2016:71-78.

[22] Velichko E., Tskhovrebov E., Shevchenko A. Environmental safety providing during heat insulation works and using thermal insulation materials. MATEC Web of Conferences 2017:106:03009. https://doi.org/10.1051/matecconf/201710603009

[23] Stec A. A., Hull T. R. Assessment of the fire toxicity of building insulation materials. Energy and Buildings 2011:43(23):498-506. https://doi.org/10.1016/j.enbuild.2010.10.015

[24] McGregor F., et al. Conditions affecting the moisture buffering measurement performed on compressed earth blocks. Building and Environment 2014:75:11-18. https://doi.org/10.1016/j.buildenv.2014.01.009

[25] Liuzzi S., et al. Hygrothermal behaviour and relative humidity buffering of unfired and hydrated lime-stabilised clay composites in a Mediterranean climate. Building and Environment 2013:61:82-92. https://doi.org/10.1016/j.buildenv.2012.12.006

[26] Hussain A., et al. Development of novel building composites based on hemp and multi-functional silica matrix. Composites Part B: Engineering 2019:156:266-273. https://doi.org/10.1016/j.compositesb.2018.08.093

[27] Walling S. A., Provis J. L. Magnesia-Based Cements: A Journey of 150 Years, and Cements for the Future? Chemical Reviews 2016:116:4170-4204. https://doi.org/10.1021/acs.chemrev.5b00463

[28] Cérézo V. Propriétés mécaniques, thermiques et acoustiques d'un matériau à base de particules végétales : approche expérimentale et modélisation théorique (Mechanical, thermal and acoustic properties of a material based on plant particles: experimental approach and theoretical modeling.). Lyon: L'Institut National Des Sciences Appliquées de Lyon 2005. (in French)

[29] Namsone E., et al. Reduction of the capillary water absorption of foamed concrete by using the porous aggregate. IOP Conference Series: Materials Science and Engineering 2017:251:012030. https://doi.org/10.1088/1757$\underline{899 X / 251 / 1 / 012030}$ 